УДК 330.341 .32

Павлюк Л.В., к.е.н., доцент

Луцький національний технічний університет

\title{
МЕХАНІЗМ УПРАВЛІННЯ ФІНАНСОВИМИ ПОТОКАМИ ПІДПРИЕМСТВА В СУЧАСНИХ УМОВАХ ГОСПОДАРЮВАННЯ
}

\author{
У науковій публікації розглядаються особливості формування та реалізації механізму управління \\ фінансовими потоками підприємства в сучасних умовах господарювання \\ Ключові слова: механізм, фінансові потоки, управління фінансовими потоками, стратегія і тактика \\ розвитку, сучасні умови господарювання.
}

Pavliuk L.

\section{MECHANISM OF MANAGEMENT OF FINANCIAL FLOWS OF ENTERPRISE IN MODERN ECONOMIC CONDITIONS}

\begin{abstract}
Features of formation and realization of the mechanism of management of financial flows of the enterprise in modern conditions of management are considered in the scientific publication

Keywords: mechanism, financial flows, financial flow management, development strategy and tactics, modern conditions of management.
\end{abstract}

Павлюк Л.В.

\section{МЕХАНИЗМ УПРАВЛЕНИЯ ФИНАНСОВЫМИ ПОТОКАМИ ПРЕДПРИЯТИЯ В СОВРЕМЕННЫХ УСЛОВИЯХ ХОЗЯЙСТВОВАНИЯ}

В научной публикации рассмотрены особенности формирования и реализации механизма управления финансовыми потоками предприятия в современных условиях хозяйствования.

Ключевые слова: механизм, финансовые потоки, управление финансовыми потоками, стратегия и тактика, современные условия хозяйствования.

Постановка проблеми у загальному вигляді i ï̈ зв'язок 3 важливими науковими та практичними завданнями. В сучасних умовах, всі господарюючі суб'єкти України, прагнуть до здійснення ефективної виробничо-господарської діяльності, яка полягає у поліпшенні фінансового стану підприємства. Але поліпшення фінансового стану підприємства передбачає і підвищення ефективності управління фінансовими потоками та їх збільшення в кінцевому результаті.

Для досягнення цього, важливу роль має успішне здійснення аналізу господарської діяльності підприємств та аналізу фінансових потоків. Адже, саме на основі аналізу фінансових потоків розробляються подальші стратегія і тактика розвитку підприємства, встановлюються оптимальні обсяги виробництва продукції, обгрунтовуються плани на перспективу, приймаються різні логістичні рішення, виявляються резерви підвищення прибутковості та рентабельності виробництва, його функціональних підрозділів тощо.

Тому, виникла гостра необхідність виокремлення важливої ролі фінансових потоків та необхідність успішного управління ними. Адже саме від розробки оптимальних методів управління останніми, а потім успішного їх впровадження, залежить не лише підвищення ефективності виробничо-господарської діяльності, але й досягнення стратегічних цілей підприємства в цілому.

Аналіз останніх досліджень, у яких започатковано вирішення проблеми.

Дослідженню механізму управління фінансовими потоками присвячені роботи багатьох вітчизняних і зарубіжних учених, серед яких: Г. Азаренкова, 3. Боді, 
О. Васюренко, А. Горбунов, В. Іванов, В. Іріков, В. Корнєєв, С. Кусакін, В. П. Медведєва, Р. Мертон, С. К. Мирзажанова, Ю. П. Морозова, В. Н. Мосіна, В. Москаленко, Е. В. Негашева, О. Олійник, К. В. Пивоварова, Г. І. Просвєтова, Л. Ю. Проурзина, Б. М. Раппопорт, В. Рєпін, В. М. Рутгайзер, І. В. Сєргєєв, Е. Л. Татарський, Е. О. Уткіна, М. А. Федотова, А. Д. Шеремет В. А. Щербакова та інші дослідники.

Цілі статті. Головною ціллю статті $\epsilon$ дослідження механізму управління фінансовими потоками підприємства в сучасних умовах господарювання.

Виклад основного матеріалу дослідження 3 повним обгрунтуванням отриманих наукових результатів. Під «фінансовими потоками» пропонуємо розуміти рух грошових коштів чи короткострокових фінансових інвестицій у процесі здійснення будь-яких видів діяльності підприємства за чітко визначений період часу.

Розробка методології управління фінансовими потоками повинна спиратися на науково-обгрунтовані принципи, що виражають динамічність і сприйнятливість до мінливих умов, а також кінцеві результати виробничо-господарської діяльності. Дослідивши та вивчивши праці вітчизняних науковців, ми здійснили спробу виділити головні принципи управління фінансовими потоками $[1,2]$ :

1. Чітка відповідність формування фінансового потоку на підприємстві загальній стратегії управління цим підприємством. Необхідно зазначити, що фінансування будьякої діяльності підприємства пов'язано з формуванням капіталу, фінансових потоків, грошових потоків, зміною їх обсягу та структури. Управління формуванням фінансовими потоками, безпосередньо, пов'язано 3 всіма іншими напрямками логістичного управління та фінансового менеджменту. Саме це й визначає необхідність поєднання управління формуванням та використанням фінансових потоків 3 іншими системами управління, зокрема, з загальною системою управління підприємством.

2. Комплексний характер формування та умови прийняття логістичних управлінських рішень. Всі управлінські рішення в області формування та використання фінансових потоків та джерела їх залучення взаємозалежні і впливають на успішність результатів фінансової діяльності підприємства в цілому. Тому систему управління формуванням та використанням фінансових потоків необхідно розглядати як комплексну систему, що забезпечить успішну реалізацію логістичних управлінських рішень. Вчасна та ефективна реалізація кожного з них забезпечить результативність діяльності підприємства в цілому.

3. Своєчасність впливу на поточний фінансовий стан підприємства. Найбільш успішні логістичні управлінські рішення в області формування та використання фінансових потоків, що були вже успішно реалізовані на підприємстві в попередньому періоді, не завжди можуть бути так же успішно реалізовані на наступних етапах його діяльності. В основному, це пов'язано з негативним впливом факторів зовнішнього середовища, а також внутрішніми умовами функціонування підприємства. Тому, системі управління фінансовими потоками необхідно пристосовуватися до динамічних умов, що враховують зміни факторів як зовнішнього, так і внутрішнього середовища.

4. Різноплановість та різносторонність підходів до розробки певних логістичних управлінських рішень. Адже підготовка таких рішень у сфері успішного та якісного формування та використання фінансових потоків повинна враховувати альтернативні варіанти дій. Причому, вибір для їх реалізації повинний бути заснований на системі ретельно відібраних критеріїв, що визначають фінансову стратегію підприємства.

5. Узгодженість та орієнтованість на стратегічні цілі розвитку досліджуваного підприємства. Адже якими успішними не здавалися б інші проекти управлінських рішень в сфері формування та використання фінансових потоків, вони повинні бути відхилені, якщо не відповідають стратегічними планам та цілям розвитку цього підприємства. 
6. Об'єктивність даних, науковість підходів та цілеспрямованість дій задля підвищення ефективності управління формування та використання фінансових потоків.

7. Реалістичність, відповідність, вчасність та достатність необхідної інформації для визначення можливих наслідків прийняття логістичних рішень та управлінських дій.

8. Використання інноваційного підходу та оволодіння умінням швидко використовувати можливості підвищення ефективності формування та використання фінансових потоків, що відкриваються ринком і науково-технічним прогресом.

Ефективна система управління формування та використання фінансових потоків, організована з урахуванням вищевикладених принципів, створює основу високих темпів нарощування фінансового потенціалу підприємства, забезпечення необхідної фінансової стійкості в процесі розвитку, постійного росту його ринкової вартості тощо.

Складність господарської діяльності підприємств в області формування та використання фінансових потоків визначають необхідність державного регулювання цим процесом.

На сучасному етапі система державного регулювання фінансовими потоками включає: регламентування мінімальних розмірів статутного капіталу підприємств; порядок проведення емісії акцій і облігацій підприємства; регулювання порядку формування інформаційної бази управління фінансовими потоками; податкове регулювання операцій, пов'язаних з формуванням і використанням фінансових потоків; регулювання кредитних операцій; валютне регулювання; регулювання ринку цінних паперів; регламентування окремих аспектів інвестиційної діяльності підприємств; регулювання норм і методів амортизації основних засобів і нематеріальних активів тощо.

У процесі управління використовується безліч різноманітних способів, підходів $\mathrm{i}$ прийомів, що дозволяють упорядкувати і ефективно організувати виконання функцій, етапів, процедур і операцій, необхідних для прийняття рішень. У сукупності вони виступають як методи управління фінансовими потоками, під якими розуміють способи здійснення управлінської діяльності, що застосовуються для постановки та досягнення іiі цілей [3].

До управління фінансовими потоками застосовуються різні групи методів. Так, до методів реалізації загальних функцій управління (планування, прогнозування, організація, координація, мотивація, аналіз і контроль) традиційно відносять організаційні, адміністративні, економічні і соціально-психологічні [4]. Причому, необхідно відмітити, що суть організаційних методів полягає в тому, що перш ніж якась діяльність буде здійснюватися, вона повинна бути спроектована, зорієнтована, регламентована та нормована. Умовою застосування адміністративних методів $\epsilon$ перевага однозначних способів рішення задач, відхилення від яких неприпустимо. На практиці ці методи реалізуються у вигляді конкретних завдань, що допускають мінімальну самостійність виконавця. Економічні методи управління припускають непрямий вплив на його об'єкт. В основі цих методів лежить економічна зацікавленість працівника в результатах своєї праці. Соціально-психологічні методи зводяться до формування сприятливого морально-психологічного клімату в колективі та до виявлення і розвитку індивідуальних здібностей кожного.

Методи розробки рішень часто пов'язують з основними науковими підходами [5]: системним, комплексним, інтеграційним, функціональним, динамічним, відтворювальним, процесним, нормативним, ситуаційним тощо. При системному підході будь-яка система (об'єкт) розглядається як сукупність взаємозалежних елементів, що має вихід (ціль), вхід, зв'язок із зовнішнім середовищем, зворотний зв'язок. При застосуванні комплексного підходу повинні враховуватися технічні, екологічні, економічні, організаційні, соціально-психологічні та інші аспекти управління і їхнього взаємозв'язку. 
Якщо упустити один з обов'язкових аспектів управління фінансовими потоками, то проблема не буде вирішена. Інтеграційний підхід до управління фінансовими потоками націлений на дослідження і посилення взаємозв'язків між окремими підсистемами і елементами системи управління, між рівнями управління по вертикалі, між суб'єктами управління по горизонталі.

Сутність функціонального підходу до управління фінансовими потоками полягає в тому, що потреба розглядається як сукупність функцій, які потрібно виконати для іiі задоволення. При застосуванні динамічного підходу об'єкт управління розглядається в діалектичному розвитку, у причинно-наслідкових зв'язках і співпідпорядкованості, проводиться ретроспективний і перспективний аналіз. Відтворювальний підхід - підхід, орієнтований на постійне поновлення виробництва, при якому воно розглядається у взаємозв'язку 3 відтворювальним циклом. Процесний підхід розглядає функції управління як взаємозалежні. Процес управління є загальною сумою усіх функцій, серією безперервних взаємозалежних дій. Сутність нормативного підходу полягає у встановленні нормативів управління по всіх підсистемах менеджменту.

Ситуаційний підхід концентрується на тому, що застосування різних методів управління визначається конкретною ситуацією. Оскільки існує велике різноманіття внутрішніх і зовнішніх факторів, не існує єдиного найкращого способу керувати об'єктом. Найефективнішим методом у конкретній ситуації є метод, що найбільше відповідає даній ситуації, максимально адаптований.

До методів прийняття логістичних управлінських рішень відносяться: методи постановки проблем, методи вирішення проблем, методи вибору рішень, методи організації виконання прийнятих рішень.

Висновки. Отож, як було доведено, ефективна система управління формуванням та використанням фінансових потоків, організована з урахуванням викладеного підходу до побудови організаційно-економічного механізму, створює основу успішного формування та управління фінансовими потоками підприємства, забезпечення необхідної фінансової стійкості в процесі розвитку, покращення фінансового стану підприємства.

Організаційно-економічний механізм управління фінансовими потоками підприємства дозволяє в повному обсязі реалізувати цілі і задачі, які стоять перед ним та в повній мірі сприяє результативному здійсненню логістичних функцій управління.

\section{Список бібліографічного опису:}

1. Бланк І. О. Фінансовий менеджмент: навч. посіб. / І.О. Бланк. - К.: Ельга, 2008. - 722 с.

2. Фінансовий менеджмент: підручник / В. П. Мартиненко, Н. І. Климаш, К. В. Багацька, І. В. Дем'яненко, [та ін.] за заг. ред. Т. А. Говорушко. - Львів «Магнолія 2006», 2014. - 344 с.

3. Карпінський Б. А. Формування збалансованості фінансових показників / Б. А. Карпінський, О. В. Герасименко // Фінанси України. - 2009. - № 10. - С.50-56.

4. Камінська І. М. Економічна сутність та джерела фінансового забезпечення регіонального розвитку / I. М. Камінська // Регіональна економіка: зб. наук. праць ЛДТУ. - Луцьк, 2009. - № 3 (9). - Ч. 1. - С. 132-147.

5. Выборова Е. Н. Финансовая диагностика: вопросы методологии / Е. Н. Выборова // Вестник Санкт-Петербургского университета. - 2010. - Вып. 4. Cер. 5. - C. 100-112.

\section{References:}

1.Blank. I.O. (2008) Finansovij management : Kyiv: Eljga, 722 p.

2.Martunenko V.P. (2014) Finansovij management: Lviv: Magnolia 2006, 344 p.

3.Karpinskij B.A. (2009) Formyvanna zbalansovanosti finansovuch pokaznukiv: Finansu Ucraine, 50-56 p.

4.Kaminska I. M. (2009) Economichna sytnistj ta djerela finansovogo zabezpechenna regionalnogo rozvutku : Lutsk, 132-147 p.

5.Vubornova E.N. Finansova diagnostuka: voprosu metodologii: Sankt-Peterbyrg, 100-112. p.

Рецензент д.е.н., професор Ковальська Л.Л. 